\title{
Border Issue: Misperception between Indonesia and Malaysia
}

\author{
Irwansyah Irwansyah ${ }^{1, *}$ \\ ${ }^{1}$ Universitas Indonesia, Communication Department, Kampus UI Depok 16424, Indonesia
}

\begin{abstract}
Indonesia and Malaysia border has been disputed and led to misperception. By using Krauss and Morsella's misperception concept, this study described that the border issue was occurred only online community member who never existed at the border area. Online community members constructed the discourse about border issue based on the agenda of mass media. While online community members and mass media lead discussion on sovereignty and nationalistic ideology, local border people concerned how they maintain the mutual relationship. The misperception which leads to conflict in online community forum showed the extent of civil conflict mediated by mass and new media.
\end{abstract}

\section{Introduction: Border Issue between Indonesia and Malaysia}

Mass media has shown the Indonesian-Malaysian relationship to be one of conflict rather than one of cooperation [1]. Conflict between Indonesia and Malaysia date to 1960. At that time, Indonesia refused to recognize the emergence of the Malaysia Federal State, which was considered a colony under British imperialism. The conflict has continued and the border dispute between Indonesia and Malaysia has resulted in high tension between the two governments, including their military forces [2].

Since both countries proclaimed their liberty, at least four serious issues concerning border claims have fueled discourse in the mass media. First was the dispute over the Sipadan-Ligitan islands, which Malaysia won through the International Tribute to Justice (ITJ) on December, 2012. Second was Malaysia's claim on the Ambalat block, which was considered a threat to the political and military forces of Indonesia. Third was the dispute over the placement of the frontier pole on the border line between West, East, and North Borneo in Indonesia and Sarawak and Sabah in Malaysia. Fourth was Malaysia's claim on Tanjung Datu, West Borneo, secured by their construction of a lighthouse in Indonesian territory [3].

Meanwhile, the development of communication and information technology has stimulated the evolution of these issues from state conflicts to personal conflicts [4]. Border area conflicts grow in the virtual world as the online community dramatizes these conflicts [5]. As a result, potential conflicts between Indonesia and Malaysia are issues of public discourse not only in the offline world and mass media but also in community-based online forums such as Topix.com ${ }^{\circledR}$.

* Corresponding author: irwansyah09@ui.ac.id 


\section{Misperception from Communication Perspective}

Argumentation and disputation concerning border conflict can be analyzed according to misperception concepts [6]. Misperception is defined as the wrong assumption about how communicators send a message about something known by other people. This may occur when people estimate the knowledge, beliefs, and values of other people. Such estimations tend to be biased if they are based on subjective knowledge and belief. This specific situation may occur when each culture uses a different sign system. Indicators of misperception include (a) different perspectives; (b) misassumptions; (c) group differentiation; (d) different communication objectives; (e) lack of collaborative conversation or dialog; and (f) use of unfamiliar words. Misperception about border issues may exist when either senders or receivers underestimate any of these six indicators.

Misperception occurs in almost every process in the exchange of ideas and messages. People have different fields of experience and frames of reference, which affect their encoding and decoding [7]. In the case of online community conversations, different subcultures may expose and learn different beliefs and values to guide them [4] in interacting and communicating with each other in the same online forum. Although misperception has been found in comparisons of Indonesian and Malaysian users' blog, facebook, and twitter accounts [1], online forums that reflect the different character of new media have not yet been studied. Therefore, this study was an exploration of the specific online forum, Topix.com, which has 250,000 online community forum members and 750,000 users every day [8]. At the same time, this study also served to confirm and compare specific topics in the online community forum, including military activity, with the actual situations in the border area between Indonesia and Malaysia.

\section{Discovering the Indonesian-Malaysian Border Conflict}

This study used netnography [9] which is adapted from ethnography. This method is also referred to as web ethnography or virtual ethnography [10]. Netnography was used to identify conflict potential based on the different perceptions among online community forum users. Because the virtual world has a legitimate culture and meaning as if in the "actual or real world" [11], one can perceive the virtual world as having the capability of taking social action to construct a new culture that may be studied ethnographically [10].

There are five procedures on doing netnography: (1) making cultural entrée, (2) gathering and analyzing data, (3) ensuring trustworthy interpretation, (4) conducting ethical research, and (5) providing opportunities for culture member feedback [9]. This section would focus on making cultural entrée and how to gather data. Analyzing data and other procedures would be discussed in different sections of the article.

Cultural entrée of this study was two threads or conversations about Indonesian and Malaysian conflict: (a) Ekspedisi Khatulistiwa-GGK, Senoi Praaq, Sarawak Rangers (Ekspedisi Khatulistiwa) and (b) "Lucu!!! Perbatasan Indonesia-Malaysia, RI Andalkan Tank Scorpion" (Tank Scorpion). These threads were selected based on (a) border conflict issues and (b) the most number of comments. Each text that contained specific discourse on country borders and military forces in border areas was included.

Moreover, the study gathered the data from the registered Malaysia forum for Topix.com ${ }^{\circledR}$ conversations focused on the border conflict between Indonesia and Malaysia. Two main themes emerged: (a) military forces from both countries and (b) the frontier areas of both countries. The military force theme was categorized into (a) main devices in defense systems, such as weapons, tanks, and combat flights and (b) military personnel strength in the border area. The uncertainty of the location of the frontier in the border area triggered conflict concerning territorial claims between Indonesia and Malaysia. This 
uncertainty occurred because frontier poles were sometimes misplaced. The misplacing of frontier poles was ascribed to the Malaysian military as a part of confrontation. Several members of the online forum indicated that the Malaysian Army Forces (Angkatan Tentara Malaysia-ATM), the Royal Malaysian Police (Polisi Diraja Malaysia), or the Sarawak Rangers (Senoi Praaq) were responsible.

The Ekspedisi Khatulistiwa thread, created by Malaysian user Formalay, contained discourse on the issue of Indonesian military activity in the border area, with 594 comments posted between September 24, 2012, and March 20, 2013. The initiator of the thread wrote that special Malaysian troops, such as the Special Action Group (Group Gerak Khas-GGK), the Sarawak Rangers (Senoi Praaq), and the Air Force of Royal Malaysia (Tentara Udara Diraja Malaysia) oversaw the expedition to make sure that the Indonesia military did not cross the border and did not execute unexpected or illegal activities. In response to the Ekspedisi Khatulistiwa thread, an Indonesian user named Forindo created the Tank Scorpion thread to convey news from Indonesia regarding the placement of Scorpion tanks along the border between Indonesia and Malaysia. The thread had 1,002 comments posted between January 7, 2003, and March 28, 2013. These two threads led to different perceptions, understandings, and responses between Indonesian and Malaysian users and members of online forums who contributed their comments.

The user name of Formalay and Forindo could be identified as insider who have strong ties to the online group and to the consumption activity [9]. The user also tend to be longstanding and frequently referenced members about border issue between Indonesia and Malaysia. However, in regards to ethical issue on netnography, this study ensured the confidentiality and anonymity of any users including Formalay and Forindo.

\section{Misperception about Border Issues on Online Forum}

As a part of analyzing data from netnography, misperception was identified through the different perspectives found in members' arguments. For example, user named Garnett from Indonesia said, "Malaysia was over reacted on Khatulistiwa Expedition . . . in contrast when lighthouse construction at Karang Unarang, the Indonesian builders were interfered by Malaysian boat patrols by moving the wave to lighthouse site . . . until day light . . . Indonesia military were not over reacted.

Misperception was also identified through the misassumptions of both parties. In the Ekspedisi Khatulistiwa thread, for example, user named Paskal assumed the Indonesian military expedition was similar to a scouting expedition: "ATM [Royal Malaysian Force] has been playing by moving the border pole. TNI [Indonesia military] has just come to get the expedition which similar to scout expedition." User named Pengamat assumed that the Indonesia military expedition was military training and showed the strength of military devices at the border. Pengamat said that the Indonesian military expedition was a show of force for the Malaysian troops: "Indonesia has shown a challenge standpoint to Malaysia troops through the training of Indonesia military nearby the border. Moreover, the time is similar to Independence Day of Malaysia. Indonesia has instructed to Trimaran ship on the sea border but Malaysia is just quiet and afraid. Where do the Royal Malaysian Force hide? On pondering room?"

Group categorization also resulted in different perceptions. The use of the names Formalay or Forindo was part of group categorization that showed users or members' affiliations to specific states. The use of Indon for Indonesian people and Malon for Malaysian people triggered members of both groups to attack each other in the virtual world. Different perceptions that could cause conflict in both countries were identified through uncollaborated conversation. Such conversations were similar to undialogical statements from both Indonesian and Malaysian users. In the Ekspedisi Khatulistiwa thread, 
four users made undialogical conversation. Garnett commented on sea patrols of Malaysia at Karang Unarang. The next user, Wes NgeXXX, commented on Java Island's (central government of Indonesia) manipulation of news facts on the field. Paskal then responded by comparing Indonesian frogmen troops with Malaysian or Korean special forces. Finally, Malaysoak responded by asking about the lonely Ambalat zone and by informing members about the Malaysian Royal Navy breeding turtles.

Misperception could also be identified through the different objectives of communication. Online discussion labeled Forindo was identified as discussion making virtual war on Malaysia. Many Indonesian users or forum members followed this objective. The thread developed by Forindo on the Malaysian forum had the fifth highest of amount of discussion traffic on Topix.com ${ }^{\circledR}$. The purpose of creating this thread was to construct negative images about the status of Malaysia in that country's forum. Comments on Forindo increased twice as fast as those in Formalay's thread, needing three fewer months than Formalay to increase conversation.

Finally, different perceptions that could cause specific conflict were identified through the way both parties used unfamiliar words. These unfamiliar words could lead users from both parties to bully and insult users from the opposite group. For example, Imoes Gigo did not understand the terminology group gerak khas (special action of military group). As a result, the user interpreted the terminology as a dance or clown group. Similarly, when Sergio Ramos used the word lari bertaburan ("escape randomly"), user Satrio said the interpretation of those words was strange and irrelevant. The user might have wanted to insult Sergio Ramos with the unfamiliar words hanjut sanan sinun ("go anywhere").

\section{Media as a Trigger of Border Conflict Discourse}

Border conflict between Indonesia and Malaysia existed in the online community forum because users did not see the real border context. Users responded to the various issues about the border based on information from mass media. Mass media reported any comments about the border conflict, including statements from sources or news makers outside the border area. These sources or news makers were representatives of government agencies [12] and used negative tone and confrontational and harsh words. Moreover, the media did not cover both sides of the story and did not confirm any of these statements with either people from the other country or the local people of both countries.

Any media news about the border conflict was a discourse between the government and people far from the border area. In the border area, the local people saw the economic gap between Indonesia and Malaysia. As long as their economic needs were covered by both markets, the locals never complained and never thought about conflict. Indonesian informants said that the real conflict was any negative news about the border. People from the House of Representatives (Dewan Perwakilan Rakyat/DPR) called for nationalism concerning the border conflict to attract the attention of their voters. The point of view of the central government concerning the border conflict was based on colonialism and current agreements about outstanding border problems. Because military elites thought border conflict to be a threat to the unity of ideology, they campaigned to enhance troop spirit to protect the border. Every dispute on media about the border area resulted in inconvenient interactions and tension between the local people and their relatives in other countries. Malaysian informants said that any inconvenient situation or tension resulting from the Indonesian media was a cause of concern not only for their family relationships but also for their economic sustainability.

Conflict in online community forums such as Topix.com ${ }^{\circledR}$ also showed the extent of civil conflict mediated by mass and new media. Seedlings of actual conflict had grown from a series of border conflicts between Indonesia and Malaysia. However, when the real 
conflict about the border between the two countries subsided, people from both countries, especially people far from the border, who wanted the continuity of conflict created a cyberspace war. Not only could war in the virtual world be used as a propaganda tool, but such cyberspace wars could also prolong real conflict [13]. From the perspective of group communication, conflict became part of the group process [14], allowing members of the group who had similar backgrounds to communicate more openly. Group members who did not share such backgrounds constructed negative communications, suggesting misconstruction of perceptions [15].

\section{Conclusion}

Debates, disputes, and conflicts about the border area between Indonesia and Malaysia are mostly triggered by mass media and then extended into new media such as online community forums. Mass media quotes statements from any sources or news makers, including people or representatives of institutions that do not understand the real situation in the border area. Although many of these sources may think about sovereignty, they are often not available to listen to the local people and to assist with their needs. Similar to the members of the online community forums from both Indonesia and Malaysia, they express their voices, ideas, opinions, and comments without thinking about the voices of the people in the border area. Both mass media and members of online community forums only respond to the issues concerning the border, including border poles and the military located at the border, attacking and defending without any accurate knowledge of what is occurring in the real field of the border area. Therefore, misperception will become more complicated because the users have no real information about the situation and life in the border area.

As a result of this study, further research should be conducted concerning border conflict from the perspectives of politicians in DPR, news makers or sources, and government officers concerned and understanding of the needs of the local people. In addition, research should be conducted concerning the creation of balance and harmony between sovereignty or nationalism and economic development at the local community level in the border area.

\section{References}

1. Irwansyah, Jakarta, UI-Press, pp. 194-234 (2012).

2. E. Fitriani,Jakarta, UI-Press, pp. 11-66 (2012).

3. M. Muhyiddin, Malaysia Hentikan Pembangunan Mercusuar di Tanjung Datu, 21 May (2014). [Online]. Available:

http://www.tempo.co/read/news/2014/05/21/078579426/Malaysia-Hentikan-

Pembangunan-Mercusuar-di-Tanjung-Datu. [Accessed 17 April 2015].

4. G. M. Bowler, The Qual. Rep., 15, 5 (2010).

5. J.-H. Shin and G. T. Cameron, Journ. Com. Quart., 80, 3 (2003).

6. R. M. Krauss and E. Morsella, "Communication and Conflict," in The Handbook of Constructive Conflict Resolution : Theory and Practice, San Faransisco, Jossey-Bass, pp. 131-143 (2001).

7. J. T. Wood, Interpersonal Communication : Everyday Encounters 6th Edition, Boston: Wadsworth, (2010).

8. websitetrafficspy.com, 23, 4 (2013). [Online]. Available: 
http://topix.com.websitetrafficspy.com/. [Accessed 234 2013].

9. R. V. Kozinets, , Jour. Mar. Res., 39 (2002).

10. J. Sumiala and M. Tikka., Com. Cult. Crit., 6, 2 (2013).

11. T. Boellstorff, Coming of Age in Second Life: An Anthropologist Explores the Virtually Human, Princeton: Princeton University Press, (2008).

12. S. Z. M. Shariff, H. A. A. Aziz, N. Yusof and B. A. N. M. Thaheer, Int. Jour. Hum. Soc. Sci., 2, 23 (2012).

13. P. Mitra, Cyberspace War : The Kashmir Propaganda Battles Move to the Web, Far East. Econ. Rev., p. 28, 5 November (1998).

14. B. A. Olaniran, Int. Jour. Conf. Man., 21, 1 (2010).

15. O. B. Ayoko, An Int. Jour., 14, 2 (2007). 